\title{
Antioxidant Activity in in Vivo and in Vitro Cultures of Onion Varieties (Bellary and CO 3)
}

\author{
Malla Ashwini, Janakiraman Balaganesh, Srinivasan Balamurugan, \\ Shanmugaraj Bala Murugan, Ramalingam Sathishkumar*
}

Plant Genetic Engineering Laboratory, Department of Biotechnology, Bharathiar University, Coimbatore, India. Email: *rsathish@buc.edu.in

Received May $17^{\text {th }}, 2013$; revised June $17^{\text {th }}, 2013$; accepted June $24^{\text {th }}, 2013$

Copyright (C) 2013 Malla Ashwini et al. This is an open access article distributed under the Creative Commons Attribution License, which permits unrestricted use, distribution, and reproduction in any medium, provided the original work is properly cited.

\begin{abstract}
The aim of the study was to evaluate the phytochemical components and antioxidant potential of methanolic and hydrophilic extracts isolated from in vivo and in vitro cultures of onion varieties of Bellary and $\mathrm{CO}$ 3. Phytochemical components like total flavonoids, phenolics, ascorbic acid and anthocyanins were analyzed. The antioxidant activities were examined by DPPH and FRAP methods. The results indicated that the both the methanolic extracts exhibited radical scavenging activity. The DPPH scavenging activity in Bellary and CO 3 onion varieties ranged from $6.5 \%$ $11.8 \%$ whereas FRAP values ranged from $0.9-3.3 \mu \mathrm{M} / 100 \mu \mathrm{g}$ FW. The total anthocyanins ranged from $9.9-29.9$ $\mathrm{mg} / \mathrm{kg}$, vitamin-C $48.6-78.6 \mathrm{mg} / \mathrm{kg}$, total phenolics and flavonoids content was 15.7 - $34.7 \mathrm{mg} / \mathrm{g} \mathrm{GAE}$ and $0.65-1.17$ $\mathrm{mg} / \mathrm{g}$ respectively. Substantial amounts of anthocyanins, phenols, flavonoids and ascorbic acid were noticed in both the varieties. Our study revealed that the possible mechanism of the biological activities in onion could be due to the free radical scavenging and antioxidant activities. The polyphenols present in the onion bulbs may be responsible for these beneficial activities. This study clearly demonstrated that both the onion varieties possess very characteristic antioxidant potential that will help us in keeping good health.
\end{abstract}

Keywords: Onion; Antioxidants; Phenolics; Flavonoids

\section{Introduction}

Vegetables and fruits are a good source of vitamins, minerals and major component like polyphenols etc. Our daily food contains many antioxidant compounds which is due to the presence of phenols, including flavonoids, isoflavonoids, and vitamin-C. Antioxidants in fruits and vegetables provide a measure of protection by preventing the oxidative stress damage. Dietary antioxidants are chemically varied, found in diverse locations and structures in plant cells and tissues. They also differ in size, water solubility and susceptibility to oxidation. Antioxidants are absorbed and metabolized in the body in a variety of ways and some antioxidants are more bioavailable than others [1]. The natural antioxidants in foods, fruits, vegetables, beverages, spices and supplements have received much attention for their nutritive value in recent years and various synthetic antioxidants have also been in commercial use.

The essential oxygen $\left(\mathrm{O}_{2}\right)$ is a fatal toxicant under specific circumstances. The charge of fuel-efficient aero-

${ }^{*}$ Corresponding author. bic catabolism cause oxidative damage to macromolecules like DNA, proteins, lipids and carbohydrates. Oxygen free radicals and reactive nitrogen species are well recognized for playing a double role as both detrimental and as valuable species. The destructive effect of free radicals causing possible biological damage known as oxidative stress and nitrosative stress occurs in biological systems when there is an overproduction of ROS/RNS on one side and a deficiency of enzymatic and non-enzymatic antioxidants on the other. Antioxidants counteract the damaging effects of reactive oxygen species (ROS) produced within the organisms. Antioxidants can be broadly defined as "any substance that, when present at low concentrations compared to those of an oxidizable substrate, significantly delays or prevents oxidation of that substrate" $[2,3]$. Vegetables, fruits and their seeds are rich source of vitamins $\mathrm{C}, \mathrm{E}$, and $\beta$-carotene etc. Several plants have been reported to contain compounds including bioflavonoids and proanthocyanidins, ellipticine and taxol, indole derivatives, dithiolthiones, phytoestrogens, which exhibit chemopreventive and/or anticancer properties. 
Phytochemicals possessing antioxidant properties are part of a refined array of secondary compounds that have evolved to help the plants to survive in the highly dynamic environment. Antioxidants scavenge free radicals that reduce risk of cancer and cardiovascular diseases. Allium cepa has been reported to have anti-microbial, anti-spasmodic, anti-cholesterolaemic, hypotensive, hypoglycemic, anti-asthmatic, anti-cancer and antioxidant properties [4-8]. Polyphenols, anthocyanins, flavonoids, quercetin, kaempferol and their glycosides have also been reported in onions [9-12]. Huge quantities of onions are consumed all over the world, as it is very popular flavoring agent. However, available information on their free radical scavenging activities is scanty. Therefore, in vitro and in vivo cultures of Bellary and $\mathrm{CO} 3$ varieties of onion were investigated for their total phenolics, antioxidant and free radical scavenging activities.

\section{Materials and Methods}

\subsection{Onion Samples}

The two onion varieties namely Bellary and CO 3 were obtained from Tamil Nadu Agricultural University, Coimbatore, Tamil Nadu.

\subsection{Sample Extraction}

The onions were cleaned and cut into small pieces. Sample $(0.5 \mathrm{gm})$ was weighed and homogenized in $5 \mathrm{ml}$ of methanol and water, until the tissue gets into a fine paste in a mortar and pestle. The samples were then centrifuged for 15 minutes at $5000 \mathrm{rpm}$ at $4^{\circ} \mathrm{C}$. The supernatant was separated and stored at $-20^{\circ} \mathrm{C}$ for further studies.

\subsection{Phytochemicals}

\subsubsection{Estimation of Total Flavonoid Content}

To $1 \mathrm{ml}$ of methanolic extract, $0.5 \mathrm{ml}$ of $2 \% \mathrm{w} / \mathrm{v} \mathrm{AlCl}_{3}$ in methanol and $0.5 \mathrm{ml}$ potassium acetate $(120 \mathrm{mM})$ were added and incubated at room temperature for 30 minutes. Absorbance was read at $415 \mathrm{~nm}$. Quercetin was used as a standard and the results were expressed as $\mathrm{mg}$ of quercetin equivalents per gm of fresh weight sample [13].

\subsubsection{Determination of Total Phenolics}

Methanolic extract $(100 \mu \mathrm{L})$ was mixed with $1 \mathrm{ml}$ of $10 \%$ Folin-Ciocalteau reagent and it was incubated at room temperature for 4 minutes. Then $2 \mathrm{ml}$ of $5 \%$ Sodium carbonate was added to above mixture and vortexed. The resultant mixture was incubated in dark for 45 minutes at room temperature. Following this, the absorbance of the sample was measured at $765 \mathrm{~nm}$ using gallic acid $(100-1000 \mu \mathrm{g} / \mathrm{ml})$ as a standard. Results were expressed as $\mathrm{mg}$ of gallic acid equivalents per $\mathrm{gm}$ of fresh weight of sample [14].

\subsubsection{Estimation of Total Ascorbic Acid}

Total Ascorbic acid was quantified according to the method described by [15], Omaye et al. (1979). Water extract $(100 \mu \mathrm{L})$ was mixed with $900 \mu \mathrm{L}$ of $5 \%$ TCA, 1 $\mathrm{ml}$ of $10 \%$ TCA and $100 \mu \mathrm{L}$ of DTC reagent. The DTC reagent was prepared using $0.04 \mathrm{~g}$ thiourea, $0.05 \mathrm{~g}$ copper sulphate, $0.3 \mathrm{~g}$ 2,4-DNPH and $10 \mathrm{ml}$ of $9 \mathrm{~N}$ sulphuric acid. The mixture was then incubated at $37^{\circ} \mathrm{C}$ for 3 hours for the formation of orange red osazone crystals. The osazone crystals were dissolved in $750 \mu \mathrm{L}$ of $85 \%$ sulphuric acid and incubated at room temperature for 30 minutes. The absorbance was measured at $540 \mathrm{~nm}$ against 5\% TCA as blank. Total ascorbic acid was expressed in mg per $\mathrm{kg}$ of fresh weight sample.

\subsubsection{Anthocyanin Assay}

Total anthocyanins were analyzed by differential $\mathrm{pH}$ method [16]. Sample (75 mg) was homogenized in $80 \mathrm{ml}$ of distilled water and centrifuged at $3000 \mathrm{rpm}$ for 15 minutes. Buffer (pH-1) was made by mixing $1.49 \mathrm{~g}$ of $\mathrm{KCl}$ with $100 \mathrm{ml}$ deionised water, then $67 \mathrm{ml}$ of $0.2 \mathrm{~N}$ $\mathrm{HCl}$ was added to $25 \mathrm{ml}$ of solution and it was made upto $100 \mathrm{ml}$ finally $\mathrm{pH}$ was adjusted to $1.0 \pm 0.1$. Buffer (pH 4.5) was prepared by dissolving $1.64 \mathrm{~g}$ of sodium acetate in $100 \mathrm{ml}$ of deionised water with $\mathrm{pH}$ adjusted to $4.5 \pm$ 0.1 . To $0.1 \mathrm{ml}$ of sample extract $25 \mathrm{ml}$ of $\mathrm{pH} 1$ buffer was mixed and absorbance was measured at $700 \mathrm{~nm}$ and $510 \mathrm{~nm}$. Sample extract $(0.1 \mathrm{ml})$ was mixed with $25 \mathrm{ml}$ of $\mathrm{pH} 4.5$ buffer and absorbance was recorded at 700 and $510 \mathrm{~nm}$. Absorbance was calculated by,

Absorbance $=\left(\mathrm{A}_{510}-\mathrm{A}_{700}\right) \mathrm{pH} 1.0-\left(\mathrm{A}_{510}-\mathrm{A}_{700}\right) \mathrm{pH}$ 4.5

\subsection{Antioxidant Capacity}

\subsubsection{DPPH Radical Scavenging Activity}

Methanolic extract $(100 \mu \mathrm{L})$ of sample was mixed with $900 \mu \mathrm{L}$ of Tris $\mathrm{HCl}$ buffer (50 mM, pH 7.4) and $2 \mathrm{ml}$ of DPPH $(0.1 \mathrm{mM}$ in methanol). The solution was incubated at room temperature for 30 minutes and the absorbance was read at $517 \mathrm{~nm}$. The percentage of DPPH scavenging activity was determined as follows, DPPH Radical Scavenging Activity $(\%)=\left[\left(\mathrm{A}_{0}-\mathrm{A}_{1}\right) / \mathrm{A}_{0}\right]$ where $\mathrm{A}_{0}$ is the absorbance of control and $\mathrm{A}_{1}$ is the absorbance of sample [17].

\subsubsection{Ferric Reducing Antioxidant Power Assay}

The total antioxidant activity in the extract was determined by a modified method [18], of Benzie and Strain (1999). The reagents included $300 \mathrm{mM}$ Acetate buffer (pH 3.6), $10 \mathrm{mM}$ TPTZ solution in $40 \mathrm{mM} \mathrm{HCl}$ and 20 $\mathrm{mM} \mathrm{FeCl} \cdot 6 \mathrm{H}_{2} \mathrm{O}$ solution. The fresh working solution was prepared by mixing $25 \mathrm{ml}$ acetate buffer, $2.5 \mathrm{ml}$ TPTZ and $2.5 \mathrm{ml} \mathrm{FeCl}{ }_{3} \cdot 6 \mathrm{H}_{2} \mathrm{O}$. The reagent must be straw yellow to light orange colour and was pre-warmed to 
$37^{\circ} \mathrm{C}$ before use. Methanolic samples $(100 \mu \mathrm{L})$ were allowed to react with $2850 \mu \mathrm{L}$ of the FRAP solution, and the change in the absorbance was monitored for 4 minutes at $593 \mathrm{~nm}$ using $\mathrm{FeSO}_{4}(200-1000 \mu \mathrm{M})$ as reference standard. The total antioxidant capacity of FRAP was calculated by the following equation, FRAP value $(\mu \mathrm{M})=$ Change in absorbance of the sample from 0 to 4th minute at $593 \mathrm{~nm} /$ change in absorbance of the blank from 0 to 4 th minute at $593 \mathrm{~nm}$.

\subsection{Statistical Analysis}

All the assays were carried out in triplicates and results are expressed as mean $\pm \mathrm{SD}$. The data were subjected to one-way analysis of variance (ANOVA) and the differences between various concentrations were determined by DMRT test using SPSS software.

\section{Results and Discussion}

The results of total phenolics, flavonoids, total anthocyanins vitamin-C content and radical scavenging assays in both the onion varieties are given in Figures 1-6.

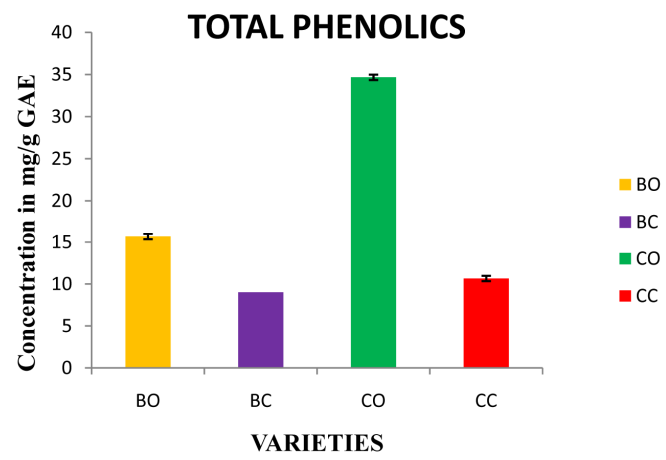

Figure 1. Estimation of total phenolics in in vivo and in vitro cultures of onion varieties (Bellary and CO 3). BO-Bellary onion, BC-Bellary callus, CO-CO 3 onion, CC-CO 3 callus.

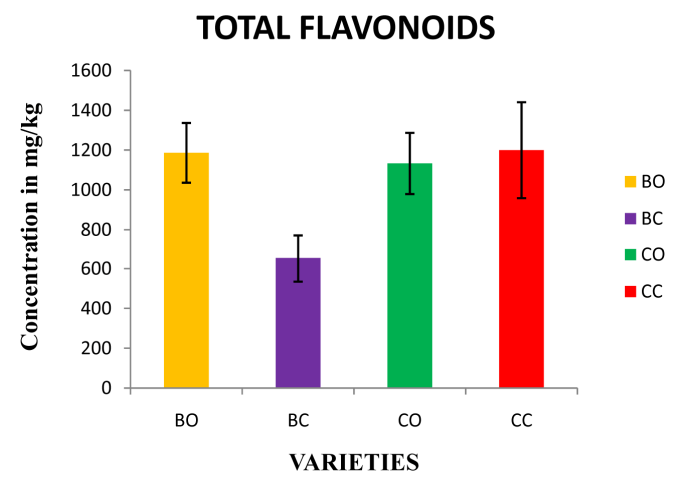

Figure 2. Determination of total flavonoids in in vivo and in vitro cultures of onion varieties (Bellary and $\mathrm{CO} 3$ ). $\mathrm{BO}-$ Bellary onion, BC-Bellary callus, CO-CO 3 onion, CCCO 3 callus.

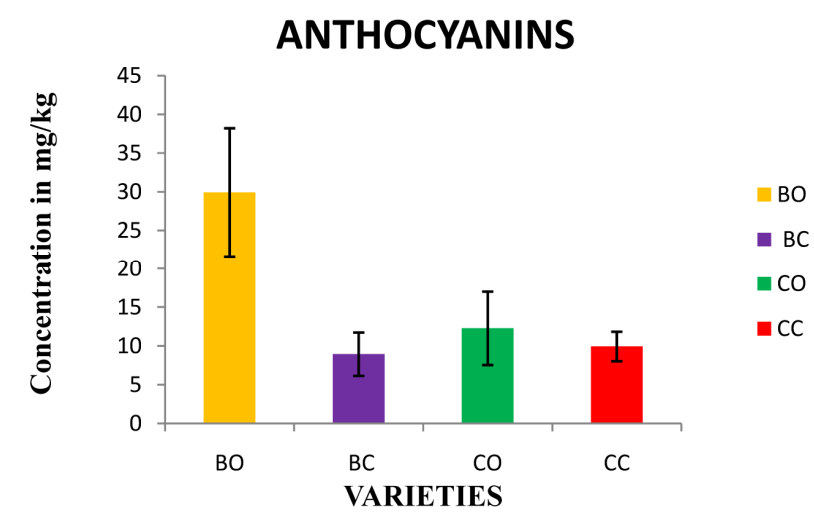

Figure 3. Estimation of Anthocyanin content in in vivo and in vitro cultures of onion varieties (Bellary and $\mathrm{CO} 3$ ). BOBellary onion, BC-Bellary callus, $\mathrm{CO}-\mathrm{CO} 3$ onion, CCCO 3 callus

\section{ASCORBIC ACID}

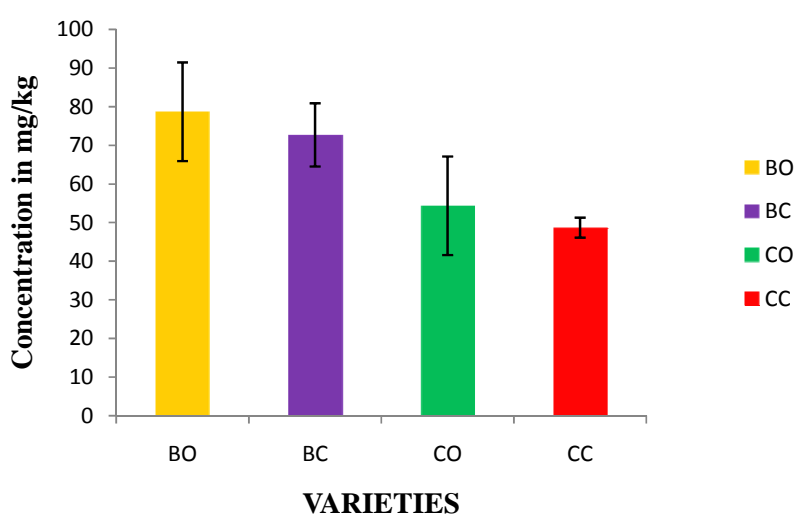

Figure 4. Estimation of ascorbic acid in in vivo and in vitro cultures of onion varieties (Bellary and CO 3). BO-Bellary onion, BC-Bellary callus, CO-CO 3 onion, CC-CO 3 callus.

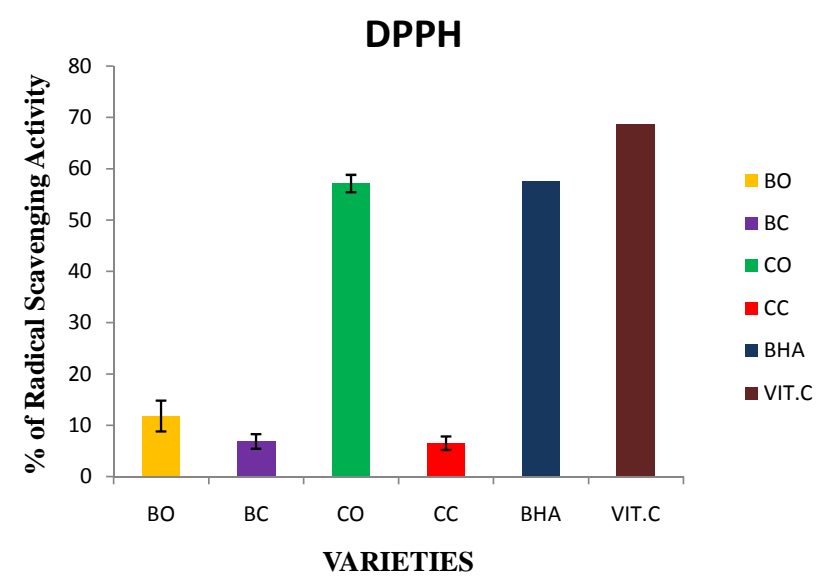

Figure 5. DPPH radical scavenging activity in in vivo and in vitro cultures of onion varieties (Bellary and $\mathrm{CO} 3$ ). $\mathrm{BO}-$ Bellary onion, BC-Bellary callus, $\mathrm{CO}-\mathrm{CO} 3$ onion, $\mathrm{CC}-$ CO 3 callus, BHA-Butyrated Hydroxy Anisole, Vit. CAscorbic acid. 


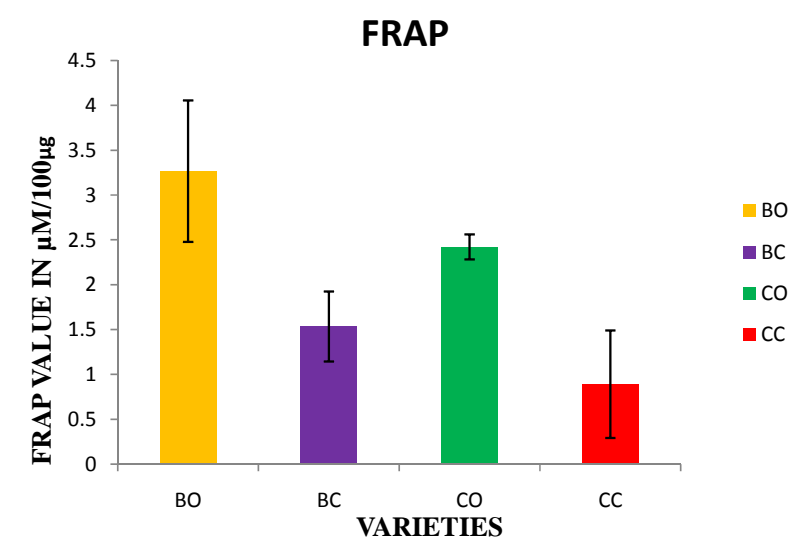

Figure 6. FRAP values of in vivo and in vitro cultures of onion varieties (Bellary and $\mathrm{CO} 3$ ). BO-Bellary onion, BC -Bellary callus, CO-CO 3 onion, $\mathrm{CC}-\mathrm{CO} 3$ callus.

\subsection{Total Phenolics}

Phenolic compounds present in the plants are responsible for its effective free radical scavenging and antioxidant activities [19]. There was a distinct difference in the phenolic content of both the varieties. However the in vitro calli showed lesser phenolic content. Bellary and CO 3 showed 15.7 and $34.7 \mathrm{mg}$ GAE (Gallic Acid Equivalent)/g FW respectively (Figure 1). The results are similar to the previous reports, where they have reported that the phenolic content of onion ranged from 4.6 to $74.1 \mathrm{mg}$ GAE/g FW [20]. Lesser polyphenol content was observed in Spanish onions [21]. Certain other investigations showed variation of phenols in fresh and frozen onions [22].

\subsection{Total Flavonoids}

Total flavonoids in the onion varieties were ranged between 0.653 to $1.17 \mathrm{mg} / \mathrm{g}$ (Figure 2). There is no significant difference in the concentration of flavonoids in Bellary $(1.18 \mathrm{mg} / \mathrm{g})$ and $\mathrm{CO} 3(1.12 \mathrm{mg} / \mathrm{g})$. This study showed higher total flavonoid content than the earlier reports (red onions: $943 \mathrm{mg} / \mathrm{kg} \mathrm{FW}$ ) [23]; (white: 185 $634 \mathrm{mg} / \mathrm{kg} \mathrm{FW}$ ) [10]; (yellow: 120 - $520 \mathrm{mg} / \mathrm{kg} \mathrm{FW}$ ) [24]; (yellow: 251 - $479 \mathrm{mg} / \mathrm{kg} \mathrm{FW}$ ) [25]; but higher than the values reported for the white varieties $(1.8 \mathrm{mg} / \mathrm{kg} \mathrm{FW})$ [26].

\subsection{Total Anthocyanins}

Total anthocyanins show marked variations in the all the samples. The Bellary showed the highest amount of anthocyanin. The overall concentration of anthocyanins varied between $9.9 \mathrm{mg} / \mathrm{kg}$ to $29.9 \mathrm{mg} / \mathrm{kg}$ fresh weight of the onion bulb (Figure 3). Gregorio et al. (2010) reported that the total content of anthocyanins in red onions ranged from 5.7 to $28.6 \mathrm{mg} / \mathrm{kg} \mathrm{FW} \mathrm{[27].} \mathrm{Our} \mathrm{results} \mathrm{showed}$ that total anthocyanins content were considerably lower than the other reports $233 \mathrm{mg} / \mathrm{kg} \mathrm{FW}$ [23]; $1090-2190$ $\mathrm{mg} / \mathrm{kg}$ DW [28]; $90 \mathrm{mg} / \mathrm{kg} \mathrm{FW} \mathrm{[29]} \mathrm{for} \mathrm{Spanish,} \mathrm{North}$ American and Italian red onions, respectively. The anthocyanin content in red onions, based on calculations of quantities of their anthocyanidins has been indicated to be $62-240 \mathrm{mg}$ of cyanidin, $0-23 \mathrm{mg}$ of delphinidin, and up to $12 \mathrm{mg}$ of peonidin per kilogram of FW [30].

\subsection{Ascorbic Acid Estimation}

The concentration was in the range of 48.6 to $78.6 \mathrm{mg} / \mathrm{kg}$ (Figure 4) of fresh weight. Ascorbic acid concentration was slightly lesser in in vitro cultures. Normally ascorbic acid content in the wild onion varieties was in the range from 50 to $100 \mathrm{mg} / \mathrm{kg}$ fresh weight [31,32].

\subsection{DPPH Radical Scavenging activity}

Highest radical scavenging activity was observed in $\mathrm{CO}$ 3 variety, (57.11\%) Natural antioxidant ascorbic acid and synthetic antioxidant butyrate hydroxyl anisole were used as control (Figure 5). Prakash et al. (1999) reported that the DPPH antioxidant activity for onion varied from $13.6 \%$ to $84.1 \%$ [20]. Other studies showed that the radical scavenging activities in onion were $20 \%-90 \%$ [33].

\subsection{Ferric Reducing Antioxidant Power Assay}

Ferric Ion Fe (II) reducing ability had marked differences among in vitro cultures. The maximum reducing power was observed in Bellary ( $0.9 \mu \mathrm{M}$ to $3.3 \mu \mathrm{M} \mathrm{Fe}$ (II) (Figure 6). The variation in reducing antioxidant power in onion was reported from $0.30 \mu \mathrm{M}$ to $2.29 \mu \mathrm{M}$ onion [34]. FRAP showed, $5.28 \mathrm{mM} \mathrm{Fe}^{+2} / \mathrm{kg}$ fresh weight activity in yellow onion [35].

\section{Conclusion}

The antioxidant capacities, total phenolic, total flavonoid, vitamin-C content, anthocyanins and antioxidant capacity of both in vitro and in vivo grown onion varieties were evaluated. It was found that methanolic extracts of onion varieties possess antioxidant and free radical scavenging properties with considerable total phenolic and flavonoid content. Our results suggested that Bellary and $\mathrm{CO} 3$ varieties of onion could be a promising source of natural antioxidants.

\section{Acknowledgements}

The authors are very thankful to, The Department of Biotechnology, Bharathiar University for supporting this research through UGC-SAP and DST-FIST funds. 


\section{REFERENCES}

[1] W. Kalt, "Effects of Production and Processing Factors on Major Fruit and Vegetable Antioxidants," Journal of Food Science, Vol. 70, No. 1, 2005, pp. 11-19. doi:10.1111/j.1365-2621.2005.tb09053.x

[2] B. Halliwell and J. M. C. Gutteridge, "Free Radicals in Biology and Medicine," 2nd Edition, Clarendon Press, Oxford, 1989.

[3] B. Halliwell, "How to Characterize a Biological Antioxidant," Free Radical Research Communications, Vol. 9, No. 1, 1990, pp. 1-32. doi:10.3109/10715769009148569

[4] E. Dorant, P. Van Den Breandt and A. Goldbohm, “Allium Vegetable Consumption, Garlic Supplement Intake and Female Breast Carcinoma Incidence," Breast Cancer Research and Treatment, Vol. 33, No. 2, 1995, pp. 163170. doi:10.1007/BF00682723

[5] S. Fukushima, N. Takada, T. Hori and H. Wanibuchi, "Cancer Prevention by Organosulfur Compounds from Garlic and Onion," Journal of Cellular Biochemistry Supplement, Vol. 67, No. 27, 1997, pp. 100-105. doi:10.1002/(SICI)1097-4644(1997)27+<100::AID-JCB1 6>3.0.CO;2-R

[6] G. Gazzani, A. Papetti, D. Massolini and M. Daglia, "Anti and Prooxidant Activity of Water-Soluble Components of Some Common Diet Vegetables and the Effect of Thermal Treatment," Journal of Agricultural and Food Chemistry, Vol. 46, No. 10, 1998, pp. 4118-4122. doi:10.1021/jf980300o

[7] B. Challier, J. Pernau and J. Viel, "Garlic, Onion and Cereal Fibre as Protective for Breast Cancer: A French Case Study," European Journal of Epidemiology, Vol. 14, No. 8, 1998, pp. 739-747. doi:10.1023/A:1007512825851

[8] D. Stajner and I. S. Varga, "An Evaluation of the Antioxidant Abilities of Allium Species," Acta Biologica Szegediensis, Vol. 47, No. 1-4, 2003, pp. 103-106.

[9] M. Rhodes and K. Prince, "Analytical Problems in the Study of Flavonoid Compounds in Onions," Food Chemistry, Vol. 57, No. 1, 1996, pp. 113-117. doi:10.1016/0308-8146(96)00147-1

[10] A. Crozier, M. E. J. Lean, M. S. Mc Donald and C. Black, "Quantitative Analysis of the Flavonoid Content of Commercial Tomatoes, Onion, Lettuce and Celery," Journal of Agricultural and Food Chemistry, Vol. 45, No. 3, 1997 , pp. 590-595. doi:10.1021/jf960339y

[11] T. Fossen, A. T. Pedersen and O. M. Andersen, "Flavonoids from Red Onion (Allium cepa)," Phytochemistry, Vol. 47, No. 2, 1997, pp. 281-285. doi:10.1016/S0031-9422(97)00423-8

[12] J. A. Vinson, "Flavonoids in Foods as in Vitro and in Vivo Antioxidants," In: B. Ma, Ed., Flavonoids in the Living System, Plenum Press, New York, 1998, pp. 151-164. doi:10.1007/978-1-4615-5335-9 11

[13] S. Chanda and R. Dave, "In Vitro Models for Antioxidant Activity Evaluation and Some Medicinal Plants Possessing Antioxidant Properties: An Overview," African Journal of Microbiology Research, Vol. 3, No. 13, 2009, pp. 981-996.

[14] V. L. Singleton and J. A. Rossi, "Colorimetry of Total
Phenolics with Phosphomolybdic-Phosphotungstic Acid Reagents," American Journal of Enology and Viticulture, Vol. 16, No. 3, 1965, pp 144-158.

[15] S. T. Omaye, J. D. Turnbull and H. E. Saubelich, "Selected Methods for the Determination of Ascorbic Acid in Animal Cells, Tissues and Fluids," Methods in Enzymology, Vol. 62, No. 1, 1979, pp. 3-10. doi:10.1016/0076-6879(79)62181-X

[16] G. W. Cheng and P. J. Breen, "Activity of Phenylalaline Ammonia-Lyase (PAL) and Concentrations of Anthocyanins and Phenolics in Developing Strawberry Fruit," Journal of the American Society for Horticultural Science, Vol. 116, No. 5, 1991, pp. 865-869.

[17] M. A. Gyamfi, M. Yonamine and Y. Aniya, "Free Radical Scavenging Action of Medicinal Herbs from Ghana:171 Thonningia Sanguine on Experimentally-Induced Liver Injuries," General Pharmacology, Vol. 32, No. 6, 1999, pp. 661-667. doi:10.1016/S0306-3623(98)00238-9

[18] I. F. F. Benzie and J. J. Strain, "Ferric Reducing Antioxidant Power Assay: Direct Measure of Total Antioxidant Activity of Biological Fluids and Modified Version for Simultaneous Measurement of Total Antioxidant Power and Ascorbic Acid Concentration," Methods Enzymology, Vol. 299, No. 1, 1999, pp. 15-27. doi:10.1016/S0076-6879(99)99005-5

[19] Y. S. Velioglu, G. Mazza, L. Gao and B. D. Oomah, “Antioxidant Activity and Total Phenolics in Selected Fruits, Vegetables and Grain Products," Journal of Agricultural and Food Chemistry, Vol. 46, No. 10, 1998, pp. 4113-4117. doi:10.1021/jf9801973

[20] D. Prakash, N. S. Brahma and G. Upadhyay, "Antioxidant and Free Radical Scavenging Activities of Phenols from Onion (Allium cepa)," International Journal of Pharmacy and Pharmaceutical Sciences, Vol. 8, 1999, pp. 200-783.

[21] S. Santas, R. Carbo, M. H. Gordon and M. P. Almajano, "Comparison of the Antioxidant Activity of Two Spanish Onion Varieties," Food Chemistry, Vol. 107, No. 3, 1999, pp. 1210-1216. doi:10.1016/j.foodchem.2007.09.056

[22] P. Ninfali and B. Mara, "Polyphenols and Antioxidant Capacity of Vegetables under Fresh and Frozen Conditions," Journal of Agricultural and Food Chemistry, Vol. 51, No. 8, 2003, pp. 2222-2226. doi:10.1021/jf020936m

[23] F. Ferreres, M. I. Gil and F. A. Toma's-Barbera, "Anthocyanins and Flavonoids from Shredded Red Onion and Changes during Storage in Perforated Films," Food Research International, Vol. 29, No. 3-4, 1996, pp. 389-395. doi:10.1016/0963-9969(96)00002-6

[24] S. Sellappan and C. C. Akoh, "Flavonoids and Antioxidant Capacity of Georgia Grown Vidalia Onions," Journal of Agricultural and Food Chemistry, Vol. 50, No. 19, 2002, pp. 5338-5342. doi:10.1021/jf020333a

[25] K. A. Lombard, E. Geoffriau and E. Peffley, "Flavonoid Quantification in Onion by Spectrophotometric and High Performance Liquid Chromatography Analysis," American Society for Horticultural Science, Vol. 37, No. 4, 2002, pp. 682-685.

[26] M. Marotti and R. Piccaglia, "Characterization of Flavonoids in Different Cultivars of Onion (Allium cepa L.)," 
Journal of Food Science, Vol. 67, No. 3, 2002, pp. 12291232. doi:10.1111/j.1365-2621.2002.tb09482.x

[27] R. M. P. Gregorio, S. G. F. Mercedes, S. G. Jesus, A. S. Rodrigues and P. F. A. Domingos, "Identification and Quantification of Flavonoids in Traditional Cultivars of Red and White Onions at Harvest," Journal of Food Composition and Analysis, Vol. 23, No. 6, 2010, pp. 592-598. doi:10.1016/j.jfca.2009.08.013

[28] H. Donner, L. Gao and G. Mazza, "Separation of Simple and Malonylated Anthocyanins in Red Onions, Allium cepa L.," Food Research International, Vol. 30, No. 8, 1997, pp. 637-643. doi:10.1016/S0963-9969(98)00011-8

[29] L. Gennaro, C. Leonardi, F. Esposito, M. Salucci, G. Madani, G. Quaglia and V. Fogliano, "Flavonoid and Carbohydrate Contents in Tropea Red Onions: Effects of Homelike Peeling and Storage," Journal of Agricultural and Food Chemistry, Vol. 50, No. 7, 2002, pp. 1904-1910. doi:10.1021/jf011102r

[30] S. Rune, F. Torgils and M. V. Ingunn, "Onions: A Source of Unique Dietary Flavonoids," Journal of Agricultural and Food Chemistry, Vol. 55, No. 25, 2007, pp. 1006710080. doi:10.1021/jf0712503
[31] K. E. Lawande, “Onion," In: K. V. Peter, Ed., Handbook of Herbs and Spices, Woodhead Publishing, Oxford, 2001.

[32] Food Standards Agency, "Mccance and Widdowson's the Composition of Foods," Cambridge: Royal Society of Chemistry, Vol. 6, 2002, p. 273.

[33] A. M. Nuutila, P. P. Riitta, A. Marjukka and O. C. KirsiMarja, "Comparison of Antioxidant Activities of Onion and Garlic Extracts by Inhibition of Lipid Peroxidation and Radical Scavenging Activity," Food Chemistry, Vol. 81, No. 4, 2003, pp. 485-493. doi:10.1016/S0308-8146(02)00476-4

[34] H. C. Yan, L. C. Chao and F. H. Hsia, "Flavonoid Content of Several Vegetables and Their Antioxidant Activity," Journal of the Science of Food and Agriculture, Vol. 80, No. 5, 2002, pp. 561-566.

[35] P. Nicoletta, S. Mauro, C. Barbara, D. R. Daniele, S. Sara, B. Marta and B. Furio, "Total Antioxidant Capacity of Plant Foods, Beverages and Oils Consumed in Italy Assessed by Three Different in Vitro Assays," The Journal of Nutrition, Vol. 133, No. 9, 2002, pp. 2812-2819. 